\title{
ANALISIS KETIMPANGAN PEMBANGUNAN DI KABUPATEN LUWU TAHUN 2011-2019
}

\author{
Tayyib Darda ${ }^{1}$; I Ketut Patra ${ }^{2}$; Sri Wahyuni Mustafa ${ }^{3}$ \\ Fakultas ekonomi dan bisnis Universitas Muhammadiyah Palopo \\ Jalan. Jend. Sudirman km. 03 binturu \\ E-mail : tayyibdarda1199@gmail.com \\ diterima: 18/10/2020; direvisi: 17/1/2021; diterbitkan: 26/9/2021
}

\begin{abstract}
This research aims to determine the size of the development inequality that occurred in Luwu Regency in 2011-2019. This study uses secondary data from the Central Statistics Agency for South Sulawesi and Luwu Regency and then analyzed using the Williamson Index and Klassen Typology. The results of this study show that: 1) Based on the Williamson Index value or the level of inequality between Luwu Regency and South Sulawesi Province, there is a relatively low position starting from 2011-2019 this is evidenced during the observation period the index value only rotates at 0.23 to 0.29 . 2) Based on the Klassen Typology Matrix, Luwu Regency was included as an underdeveloped area during the observation period except in 2013, 2014, 2015 in which Luwu Regency was a fast growing area.
\end{abstract}

Keywords: Development Inequality, Williamson Index, Klassen Typology

\section{PENDAHULUAN}

Pembangunan dapat diartikan sebagai upaya yang berkelanjutan untuk tercapainya kesejahteraan masyarakat. Karena berkelanjutan maka terdapat proses yang panjang, oleh karena itu pembangunan tidak dapat terealisasi dengan instan dan juga mesti ada kolaborasi yang sifatnya serentak atau bersamaan agar pembangunan dapat selaras segala bidang dari segi kehidupan. Bidang kehidupan pembangunan harus sama merata agar pembangunan tidak timpang tindih karena pembangunan kembali lagi adalah hal yang sifatnya kolaborasi dari setiap bidang kehidupan, sebut saja pada bidang pendidikan, sosial budaya, teknologi, infrastruktur serta bidang lain yang menjadi pelopor sekaligus bagian dari pembangunan.

Tolak ukur dari keberhasilan pembangunan dapat dilihat pada pertumbuhan ekonomi yang membaik, struktur ekonomi yang stabil, infrastruktur yang memadai, taraf kesejahteraan yang tinggi, serta kecilnya angka ketimpangan pembangunan antar daerah. Tentu semua itu dapat terealisasi apabila modal terpenuhi, termasuk modal finansial yang memadai, karena pembangunam harus dilakukan secara agregat maka pengumpulan modal secara agregat membutuhkan dana yang lebih.

Pembangunan ekonomi dapat terealisasi maksimal apabila pembangunan tidak berfokus hanya pada satu titik saja akan tetapi pembangunan serentak diberbagai titik sehingga tercapainya kesejahteran masyarakat yang egaliter dan berkurangnya akan ketimpangan.

Beberapa penelitian sebelumnya telah menunjukkan bahwa ada pembangunan ekonomi yang hanya berfokus pada satu daerah sehingga daerah lainya tertinggal dan terjadi ketimpangan seperti (Hidayah dan tallo;2020) menyebutkan bahwa berdasarkan Indeks Williamson tingkat ketimpangan di Jawa tengah berada pada angka 0,69 ( sangat tinggi) dan beberapa kabupaten termasuk sebagai daerah tertinggal. Penelitian (Maulana;2019) 
menunjukkan angka ketimpangan berdasarkan Indeks Williamson di Provinsi Kalimantan Selatan cukup tinggi yaitu sekitar pada angka 0,5 dan klasifikasi kabupatenya berada pada kuadran 2 (pendapatan tinggi, pertumbuhan ekonomi rendah), dan kuadran 4 ( pendapatan rendah, pertumbuhan ekonomi lambat) hal disebabkan pada tahun tertentu hasil coal mining yang berpengaruh sangat signifikan.

Pada lain sisi lain ada daerah yang ketimpangannya cukup rendah seperti pada penelitian (nurhuda;2012) menyebutkan bahwa di rata-rata pada Provinsi Jawa timur ketimpangannya berkisar 0,1 ( rendah) berdasarkan analisis Indeks Williamson, namun kota Surabaya dan Kabupaten kediri memiliki pendapatan yang cukup tinggi jika dibandingkan dengan kota/kabupaten lain. Hal ini dikarenakan dua kota tersebut sangat mengandalkan sektor industri dan perdagangan.

Ketimpangan pembangunan adalah perbedaan taraf kesejahteraan masyarakat yang terjadi dibeberapa daerah/wilayah, sehingga hal ini biasanya menampilkan kelas kelas daerah yakni daerah yang memiliki taraf kesejahteraan tinggi dan yang rendah.

Kabupaten Luwu merupakan salah satu kabupaten yang terletak didaerah luwu raya Provinsi Sulawesi Selatan dan merupakan bagian dari daerah kerajaan luwu. Kabupaten ini memiliki luas 3.000,25 km2 serta memiliki 22 kecamatan dan 227 desa. Kabupaten ini telah melakukan pemekeran dan menghasilkan kota Palopo sebagai kota baru pada tahun 2002.

Kabupaten Luwu adalah daerah yang wilayah administratifnya memiliki beberapa kecamatan yang terpisah dari pusat kabupaten, yaitu kecamtan yang berada pada daerah Walenrang - Lamasi
(WAL-MAS). Tentu hal ini adalah tantangan pembangunan bagi pemerintah. "Masussahkan kami yato tuo jio daerah walmas apa perputaran ekonomi tae na terasa, dio ri daerah belopa ri na sekitarna perputaran ekonomi riputara. Umba pa yake la morai kimangarusu sura sura morai pi ki limbang kota makanya di kampa kampa ii te terbentuk madomi kabupaten jio walmas" Penduduk daerah Walmaas. Pemekeran daerah adalah menjadi energi untuk meminimalisir ketimpangan karena setiap penduduk lokal beranggapan bahwa warga lokal memiliki ketertarikan lebih dan pengenalan lebih kuat didaearahnya untuk meningkatkan taraf kesejahteraan.

\section{TINJAUAN PUSTAKA}

Pembangunan ekonomi bukanlah sebuah topik baru dalam ilmu ekonomi karena studi tentang pembangunan ekonomi telah menarik perhatian para ekonom sejak zaman Merkantilis, Klasik, sampai Marx dan Keynes (Arsyad, 2014)

Todaro \& Smith (2003) menyatakan bahwa keberhasilan pembangunan ekonomi suatu negara ditunjukkan oleh tiga nilai pokok, yaitu (1) berkembangnya kemampuan masyarakat untuk memenuhi kebutuhan pokoknya (sustenance), (2) meningkatnya rasa harga diri (selfesteem) masyarakat sebagai manusia, dan (3) meningkatnya kemampuan masyarakat untuk memilih (freedom from servitude) yang merupakan salah satu dari hak asasi manusia.

Sukirno (2009) pertumbuhan ekonomi berarti perkembangan fisikal produksi barang dan jasa yang berlaku disuatu negara, seperti pertambahan dan jumlah produksi barang industri, perkembangan infrastruktur, pertambahan jumlah sekolah, pertambahan produksi sektor jasa dan pertambahan produksi barang modal.

Produk Domestik Regional Bruto dapat diartikan sebagai hasil kinerja 
perekonomian suatu wilayah pada kurun waktu atau periode tertentu dapat digambarkan dengan menggunakan indikator makro ekonomi yang disebut Produk Domestik Regional Bruto (PDRB). Pada metode perhitungan PDRB terdapat tiga konsep pendekatan diantaranya : a) Pendekatan Produksi, b) Pendekatan pengeluaran, dan c) Pendekatan Pendapatan (Afini,2019).

Menurut Badan Pusat Statistik (2020) penduduk adalah semua orang yang berdomisili di wilayah geografis Republik Indonesia selama enam bulan atau lebih dan atau mereka yang berdomisili kurang dari enam bulan tetapi bertujuan untuk menetap.

Ketimpangan pembangunan adalah adanya perbedaan taraf kesejahteraan masyarakat yang diakibatkan oleh faktor-faktor tertentu. Ketimpangan pembangunan umumnya terjadi pada aspek pendapatan, spasial dan sektoral. Petunjuk awalnya adalah golongan kaya makin kaya sedangkan kaum miskin makin miskin, wilayah maju terus berkembang pesat meninggalkan wilayah terbelakang serta adanya sektor unggulan yang berkontribusi besar bagi pembangunan, sedangkan sektor non unggulan yang membebani (Mopangga, 2010)

Ketimpangan pembangunan juga dapat dilihat secara vertikal yakni perbedaan pada distribusi pendapatan serta secara horizontal yakni perbedaan antara daerah maju dan terbelakang (Sjafrizal, 2008).

Indeks Williamson (IW) adalah ukuran disparitas pendapatan antardaerah yang pertama kali dikembangkan oleh Jeffrey G. Williamson , Pada tahun 1965, Williamson meniliti hubungan disparitas daerah dengan tingkat pembangunan ekonomi . Indeks Williamson dapat digunakan untuk mengetahui ketimpangan pembangunan antar kab/kota yang terjadi disuatu Provinsi (Sjafrizal:2008).

Analisis Tipologi Klassen merupakan alat analisis yang digunakan untuk mengetahui bagaimana gambaran tentang pola dan struktur pertumbuhan ekonomi masing-masing suatu wilayah (Sjafrizal:2008).

\section{METODE PENELITIAN}

Penelitian ini merupakan penelitian analisis kuantitatif deskriptif yang menggunakan angka-angka dalam menganlisis. Adapun alat analisis yang digunakan pada penelitian ini adalah Indeks Williamson dan Tipologi Klassen untuk mengetahui besar atau kecilnya ketimpangan pembangunan yang terjadi di Kabupaten Luwu, dengan menggunakan data Produk Domestik Regional Bruto Perkapita dan Jumlah Penduduk pada tahun 2011-2019.

Penelitian ini dilaksanakan di Kabupaten Luwu dan menggunakan waktu selama tiga bulan, dimulai pada bulan Maret sampai Mei tahun 2020.

Data yang digunakan pada penelitian ini adalah data sekunder yang sifatnya time series mulai dari tahun 2011-2019. Adapun sumber data pada penelitian ini adalah Badan Pusat Statistik (BPS) Kabupaten Luwu dan Badan Pusat Statistik Provinsi Sulawesi Selatan.

Metode pengumpulan data untuk mencapai tujuan dalam penelitian ini seluruhnya dilakukan melalui studi pustaka dengan mengambil data dari Badan Pusat Statistik, sehingga tidak diperlukan teknik sampling serta kuesioner.

\section{HASIL DAN PEMBAHASAN}

Berdasarkan nilai yang dikeluarkan oleh PDRB harga konstan pola laju pertumbuhan perekonomian Kabupaten luwu berfluktuatif dan cenderung menurun peningkatanya pada akhir tahun-tahun pengamatan namun 
Jurnal Ilmiah Ekonomi dan Bisnis

Vol. 18. No.2,September $2021: 176-182$

EISSN : $2442-9813$

ISSN : $1829-9822$

pada saat yang sama pula Produk Domestik Regional Bruto yang berdasarkan harga konstan tidak mengalami penurunanan pada tiap tahunya.

Tabel 1 Produk Domestik Regional Bruto Kabupaten Luwu berdasarkan harga konstan dan pertumbuhan ekonomi pada tahun 20112019.

\begin{tabular}{lll}
\hline Tahun & $\begin{array}{l}\text { PDRB Berdasarkan } \\
\text { Harga Konstan }\end{array}$ & $\begin{array}{l}\text { Laju pertumbuhan } \\
\text { ekonomi (persen) }\end{array}$ \\
2011 & Rp.5874844.74 & $7.89 \%$ \\
2012 & Rp.6698538.66 & $7 \%$ \\
2013 & Rp.7681017.60 & $7.74 \%$ \\
2014 & Rp.9018397.18 & $8.81 \%$ \\
2015 & Rp.10362514.60 & $7.26 \%$ \\
2016 & Rp.11851862.13 & $7.88 \%$ \\
2017 & Rp.13026830.89 & $6.79 \%$ \\
2018 & Rp.14441940.32 & $6.86 \%$ \\
\hline 2019 & Rp15657617.51 & $6.2 \%$ \\
\hline & Analisis & ketimpangan
\end{tabular}

pembangunan pada penelitian ini menggunakan alat ukur Indeks Williamson untuk mengetahui seberapa besar angka ketimpangan yang terjadi pada tahun 2010 sampai tahun 2019 di Kabupaten Luwu dan sebagai perbandingannya adalah Provinsi Sulawesi Selatan.

Dibawah ini akan ditampilkan data yang digunakan untuk menghitung nilai angka ketimpangan pembangunan yang terjadi di Kabupaten Luwu.

\begin{tabular}{lllll}
\hline $\begin{array}{l}\text { Tahu } \\
\mathrm{n}\end{array}$ & $\begin{array}{l}\text { PDRB } \\
\text { Perkapita } \\
\text { Kabupaten } \\
\text { Luwu }\end{array}$ & $\begin{array}{l}\text { PDRB } \\
\text { Perkapita } \\
\text { Sul-Sel }\end{array}$ & $\begin{array}{l}\text { Jumlah } \\
\text { Pendud } \\
\text { uk } \\
\text { Luwu }\end{array}$ & $\begin{array}{l}\text { Rata-rata } \\
\text { jumlah } \\
\text { Pendudu } \\
\text { k } \\
\text { Provinsi } \\
\text { Sulawesi } \\
\text { Selatan }\end{array}$ \\
\hline 2011 & 17,43334275 & 24,31166 & 335828 & 338152 \\
& & 609 & & \\
2012 & 19,67317391 & 27,67090 & 338609 & 341259 \\
& & 607 & & \\
2013 & 22,34198368 & 31,02792 & 343793 & 347585 \\
& & 59 & & \\
2014 & 25,98242900 & 35,34488 & 347096 & 351340 \\
& & 183 & & \\
\hline 2015 & 29,58875502 & 39,95047 & 350218 & 355013 \\
& & 762 & & \\
\hline
\end{tabular}

\begin{tabular}{|c|c|c|c|c|}
\hline 2016 & 33,54835479 & $\begin{array}{l}43,81739 \\
194\end{array}$ & 353277 & 358599 \\
\hline 2017 & 36,56089836 & $\begin{array}{l}47,82211 \\
062\end{array}$ & 356305 & 362096 \\
\hline 2018 & 40,20483984 & $\begin{array}{l}52,63578 \\
054\end{array}$ & 359209 & 365499 \\
\hline 2019 & 43,24986122 & $\begin{array}{l}57,02555 \\
497\end{array}$ & 362027 & 368802 \\
\hline
\end{tabular}
(2020)

Berdasarkan tabel di atas dan setelah di masukkan ke formula indeks williamson maka di hasil nilai indeks williamson sebagai berikut :

Tabel 3 Hasil analisis Indeks Williamson

\begin{tabular}{|c|c|c|c|}
\hline Tahun & Hasil indeks williamson & Perubahan & $\begin{array}{l}\text { Klasifikasi } \\
\text { angka } \\
\text { Ketimpang } \\
\text { an }\end{array}$ \\
\hline 2011 & 0,28 & - & Rendah \\
\hline 2012 & 0,29 & $+0,01$ & Rendah \\
\hline 2013 & 0,28 & $-0,01$ & Rendah \\
\hline 2014 & 0,26 & $-0,02$ & Rendah \\
\hline 2015 & 0,26 & $\begin{array}{l}\text { Tidak } \\
\text { berubah }\end{array}$ & Rendah \\
\hline 2016 & 0,23 & 0,03 & Rendah \\
\hline 2017 & 0,23 & $\begin{array}{l}\text { Tidak } \\
\text { berubah }\end{array}$ & Rendah \\
\hline 2018 & 0,23 & $\begin{array}{l}\text { Tidak } \\
\text { berubah }\end{array}$ & Rendah \\
\hline 2019 & 0,24 & $+0,01$ & Rendah \\
\hline
\end{tabular}

Sumber : Badan Pusat Statistik (2020); data diolah

Pada tabel 3 diatas menjelaskan tingkat ketimpangan antara Kabupaten Luwu jika dibandingkan dengan Provinsi Sulawesi selatan berdasarkan pada analisis Indeks Williamson. Angka ketimpangan ditunjukkan dengan koefesien 0-1, semakin dekat ke angka nol menunjukkan angka ketimpangan yang rendah, sebaliknya jika mendekati atau sampai dengan angka satu makan tingkat ketimpangan akan semakin tinggi.

Sehingga dapat dilihat bahwa tingkat ketimpangan antar Kabupaten Luwu dan Provinsi Sulawesi Selatan posisi yang relatif rendah mulai dari tahun 2011 sampai dengan tahun 2019 atau sembilan tahun pengamatan. Tabel di atas menggambarkan angka ketimpangan yang kecil atau pembangunan yang terjadi merata apabila 
Kabupaten Luwu diperbandingkan dengan rata-rata di Provinsi Sulawesi Selatan.

Pengklasifikasian

berdasarkan Tipologi menggunakan indikator pertumbuhan ekonomi dan PDRB (Produk Domestik Regional Bruto) Perkapita. Oleh karenanya untuk melakukan analisis dengan model tipologi klasssen pada dengan angka koefesien Indeks Williamson 0,24- 0,29 (rendah).

Penelitian ini diperlukan data terkait pertumbuhan ekonomi dan PDRB Perkapita Kabupaten Luwu dan Provinsi Sulawesi Selatan.

Tabel 4 Laju Pertumbuhan Ekonomi Kabupaten Luwu dan Provinsi Sulawesi Selatan pada tahun 2011-2019 (Persen)

\begin{tabular}{llll}
\hline Tahun & \multicolumn{2}{l}{ Laju Pertumbuhan Ekonomi } & \\
& Kabupaten Luwu & $\begin{array}{l}\text { Provinsi } \\
\text { Selatan }\end{array}$ & Sulawesi \\
2011 & 7.89 & 8.13 & \\
2012 & 7 & 8.87 & \\
2013 & 7.74 & 7.62 & \\
2014 & 8.81 & 7.54 & \\
2015 & 7.26 & 7.19 & \\
2016 & 7.88 & 7.42 \\
2017 & 6.79 & 7.21 \\
\hline 2018 & 6.86 & 7.06 \\
\hline 2019 & 6.2 & 6.92 \\
\hline
\end{tabular}

Sumber : Badan Pusat StatistikSulawesi Selatan (2020)

Tabel 5 Produk Domestik Regional Bruto (PDRB) Perkapita Kabupaten Luwu dan Provinsi Sulawesi Selatan.

\begin{tabular}{llll}
\hline $\begin{array}{l}\text { Tahu } \\
\mathrm{n}\end{array}$ & $\begin{array}{l}\text { PDRB Perkapita } \\
\text { Luwu }\end{array}$ & Kabupaten & $\begin{array}{l}\text { PDRB Perkapita } \\
\text { Sul-Sel }\end{array}$ \\
2011 & 17,43334275 & 24,31166609 \\
2012 & 19,67317391 & 27,67090607 \\
2013 & 22,34198368 & 31,0279259 \\
2014 & 25,98242900 & 35,34488183 \\
2015 & 29,58875502 & 39,95047762 \\
2016 & 33,54835479 & 43,81739194 \\
2017 & 36,56089836 & 47,82211062 \\
\hline
\end{tabular}

\begin{tabular}{lll}
\hline 2018 & 40,20483984 & 52,63578054 \\
\hline 2019 & 43,24986122 & 57,02555497
\end{tabular}

Sumber : Badan Pusat Statistik Provinsi Sulawesi Selatan (2020)

Berdasarkan data yang tersedia yakni PDRB Perkapita dan Laju pertumbuhan ekonomi Kabupaten Luwu dan Provinsi Sulawesi Selatan maka didapatkan klasifikasi daerah dibawah ini.

Tabel 6 Klasifikasi Berdasarkan Tipologi Klassen Kabupaten Luwutahun 20112019

\begin{tabular}{|c|c|c|c|c|}
\hline $\begin{array}{l}\text { Tahu } \\
\mathrm{n}\end{array}$ & $\begin{array}{l}\text { Perbandinga } \\
\mathrm{n} \quad \text { PDRB } \\
\text { Perkapita }\end{array}$ & $\begin{array}{l}\text { Perbandigan } \\
\text { Laju } \\
\text { Pertumbuha } \\
\text { n Ekonomi }\end{array}$ & $\begin{array}{l}\text { Hasil } \\
\text { Kuadra } \\
\mathrm{n}\end{array}$ & $\begin{array}{l}\text { Klasifikas } \\
\text { i }\end{array}$ \\
\hline 2011 & $\mathrm{Yi}<\mathrm{y}$ & $\mathrm{Ri}<\mathrm{r}$ & $\begin{array}{l}\text { Kuadra } \\
\mathrm{n} \text { IV }\end{array}$ & $\begin{array}{l}\text { Daerah } \\
\text { Tertinggal }\end{array}$ \\
\hline 2012 & $Y i<y$ & $\mathrm{Ri}<\mathrm{r}$ & $\begin{array}{l}\text { Kuadra } \\
\text { n IV }\end{array}$ & $\begin{array}{l}\text { Daerah } \\
\text { Tertinggal }\end{array}$ \\
\hline 2013 & $\mathrm{Yi}<\mathrm{y}$ & $\mathrm{Ri}>\mathrm{r}$ & $\begin{array}{l}\text { Kuadra } \\
\mathrm{n} \text { II }\end{array}$ & $\begin{array}{l}\text { Daerah } \\
\text { Maju tapi } \\
\text { tertekan }\end{array}$ \\
\hline 2014 & $Y i<y$ & $\mathrm{Ri}>\mathrm{r}$ & $\begin{array}{l}\text { Kuadra } \\
\mathrm{n} \text { II }\end{array}$ & $\begin{array}{l}\text { Daerah } \\
\text { Maju tapi } \\
\text { tertekan }\end{array}$ \\
\hline 2015 & $\mathrm{Yi}<\mathrm{y}$ & $\mathrm{Ri}>\mathrm{r}$ & $\begin{array}{l}\text { Kuadra } \\
\mathrm{n} \text { II }\end{array}$ & $\begin{array}{l}\text { Daerah } \\
\text { Maju tapi } \\
\text { tertekan }\end{array}$ \\
\hline 2016 & $\mathrm{Yi}<\mathrm{y}$ & $\mathrm{Ri}>\mathrm{r}$ & $\begin{array}{l}\text { Kuadra } \\
\mathrm{n} \text { II }\end{array}$ & $\begin{array}{l}\text { Daerah } \\
\text { Maju tapi } \\
\text { tertekan }\end{array}$ \\
\hline 2017 & $\mathrm{Yi}<\mathrm{y}$ & $\mathrm{Ri}<\mathrm{r}$ & $\begin{array}{l}\text { Kuadra } \\
\text { n IV }\end{array}$ & $\begin{array}{l}\text { Daerah } \\
\text { Tertinggal }\end{array}$ \\
\hline 2018 & $\mathrm{Yi}<\mathrm{y}$ & $\mathrm{Ri}<\mathrm{r}$ & $\begin{array}{l}\text { Kuadra } \\
\text { n IV }\end{array}$ & $\begin{array}{l}\text { Daerah } \\
\text { Tertinggal }\end{array}$ \\
\hline 2019 & Yi<y & $\mathrm{Ri}<\mathrm{r}$ & $\begin{array}{l}\text { Kuadra } \\
\mathrm{n} \text { IV }\end{array}$ & $\begin{array}{l}\text { Daerah } \\
\text { Tertinggal }\end{array}$ \\
\hline
\end{tabular}

Sumber : Badan Pusat Staistik Provinsi Sulawesi Selatan (2020).

Tabel 6 diatas menunjukkan kategori daerah Kabupaten Luwu berdasarkan Tipologi Klassen yang terbagi dalam 4 kategori yaitu : a) kuadran I (daerah maju dan tumbuh pesat), b) kuadran II (Daerah maju tapi tertekan), c) kuadran III (daerah potensial dan bisa berkembang pesat), d) kuadran iv ( daerah tertinggal).

Pada masa pengamatan yakni tahun 2011-2019 Klasifikasi Tipologi Klassen pada Kabupaten Luwu hanya berada pada dua kuadran yakni Kuadran IV dan kuadran II Kuadran berarti Kabupaten Luwu berada pada daerah yang maju akan tetapi tertekan 
sedangkan kuadran IV menggambarkan Kabupaten Luwu merupakan daerah yang tertinggal. Perbedaan Kuadran Tipologi Klaasen pada Kabupaten Luwu di sebabkan karena Laju pertumbuhan ekonomi Kabupaten Luwu terkadang berubah dan melampui laju pertumbuhan ekonomi Provinsi Sulawesi Selatan sedangkan pada Produksi PDRB Perkapita Kabupaten Luwu selama masa pengamatan terus berada pada posisi rendah dibanding dengan PDRB Perkapita Provinsi Sulawesi Selatan

\section{KESIMPULAN DAN SARAN}

Berdasarkan pada pembahasan dan data yang sudah diolah maka dapat tarik kesimpulan sebagai berikut :

1. Selama masa pengamatan tahun 20112019 angka disparitas pembangunan pada Kabupaten Luwu cenderung rendah hal ini terbukti dengan hasil analisis Indeks Williamson yang berada pada koefesien 0,20 dan yang paling tinggi 0,29 ( angka ketimpangan rendah) hal ini disebabkan karena pendapatan perkapita masyrakat dikabupaten Luwu dapat menyesuaikan dengan pendapatan rata-rata masyarakat Sulawesi selatan. Meskipun begitu pendapatan perkapita masyarakat Kabupaten Luwu sedikit lebih rendah dibanding rata-rata masyarakat Sulawesi selatan

2. Selama masa pengamatan tahun 20112019 pertumbuhan ekonomi dan Produk Domestik Regional Bruto (PDRB) menjadi penyebab Kabupaten Luwu tersebar pada beberapa kuadran di Tipologi Klassen yakni kuadran II ( Daerah yang maju tapi tertekan) pada tahun 2013,2014,2015 dan Kuadran IV ( Daerah yang tertinggal). Perbedaan pada tiap tahun ini disebabkan karena kontribusi PDRB di Kabupaten luwu tidak maksimal dikarenakan beberapa sektor perekonomian tidak aktif dan hanya cenderung pada sektor pertanian.

\section{DAFTAR PUSTAKA}

Arsyad, L. (2014). Konsep dan pengukuran pembangunan ekonomi. Lincolin Arsyad, 1-46.

Afini,N.(2019).Pengaruh PDRB Perkapita Dan Indeks Pembangunan Manusia (IPM) Terhadap Pemerataan Pendapatan DiProvinsiJawa Timur .Jurnal Dinamika Ekonomi Pembangunan, 2(2),172-177.

Asih, W.(2015).Analisis ketimpangan dalam pembangunan ekonomi antar kecamatan di kabupaten cilacap tahun 2004-

2013,http://eprints.uny.ac.id/23801/1

Hidayah, R. A. D. N., \& Tallo, A. J. (2020). Analisis Ekonomi Provinsi Jawa Tengah Periode 2015-2019 dengan Metode Indeks Williamson, Tipologi Klassen dan Location Quotient. Aksara: Jurnal Ilmu Pendidikan Nonformal, 6(3), 339-350.

Bakri, B., Syafrizal, S., \& Aimon, H. (2015). Analisis Ketimpangan Pembangunan Antar Kabupaten/Kota Di Sumatera Barat Dan Kebijakan Penanggulannya. Jurnal Kajian Ekonomi, 4(7), 103017.

Badan pusat statistik.(2020) Kontribusi PDRB Kabupaten/kota. https://sulsel.bps.go.id/statictable/2020 /02/28/231/kontribusi-PDRB-

kabupaten-kota-terhadap-total-PDRBkabupaten-kota-atas-dasar-hargaberlaku-menurut-lapangan-usaha2010-2019-persen-

Badan Pusat Statistik.(2020) Presentase Penduduk Miskin. https://sulsel.bps.go.id/statictable/2019 /05/10/91/persentase-pendudukmiskin-provinsi-sulawesi-selatan2000-2018-

Badan Pusat Statistik.(2020). Laju Pertumbuhan PDRB Kabupaten Luwu. https://luwukab.bps.go.id/dynamictabl 
e/2020/04/07/32/laju-pertumbuhanPDRB-kabupaten-luwu-atas-dasarharga-konstan-menurut-pengeluaran2011-2019

Dewi, R. (2018). Analisis Ketimpangan Pembangunan Di Provinsi SulawesiSelatan Tahun 2010-2016.

Dhyatmika, Ketut Wahyu dan Atmani, H. (2013). Analisis Ketimpangan Pembangunan ProvinsiBanten Pasca Pemekaran.

Http://Eprints.Undip.Ac.Id/38984/, 2, 96.

Ekwarso, H., Taryono, \& Isyandi. (2016). Analisis Ketimpangan Pembangunan Antar Wilayah Kecamatan Di Kota Dumai. Jurnal Sosial Ekonomi Pembangunan, VII(19), 1-16.

Hamid, M., Siradjuddin, S., \& Rusydi, B. U. (2017). Analisis Pertumbuhan Ekonomi Dan Ketimpangan Pendapatan Antar Kabupaten Di Provinsi Sulawesi Barat. EcceS (Economics, Social, and Development Studies), 4(2), 149. https://doi.org/10.24252/ecc.v4i2.443 1

Plane, David A. And Peter A. Rogerson. (1004). The Geographical Analysis of Population with Applications to Planning and Bussiness. Singapore: John Wiley and Sons

Hartono,B.(2008). Analisis Ketimpangan Pembangunan Ekonomi Di ProvinsiJawa Tengah ,(Doctoral Dissertation , Program Pascasarjana Universitas Dipenorogo).

Irkham, M. (2019). Analisis ketimpangan wilayah. Akuntabel, 16(1), 98-110.

Karim, N. A., Utama, I. D., \& Aryanto, R. (2019). $S$ tudi Komparasi Ketimpangan Pembangunan Ekonomi Antar Kabupaten / Kota di ProvinsiJawa Barat ( Pendekatan Analisis Tipologi Klassen dan Analisis Indeks Wiliamson ' $s$ ) Comparative Study of Economic Development Inequality among
Regency / City in West Jav. III(1), 2834.

Kuznets S. 1971. Economics Growth Of Nations. Cambridge: Harvard University Press.

Mopangga, H. (2010). Analisis Ketimpangan Pembangunan dan Pertumbuhan Ekonomi di ProvinsiGorontalo Herwin Mopangga SEKOLAH PASCASARJANA. Trikonomika, 10(1), 40-51.

Mantra, Ida Bagoes. (2003). Demografi Umum. Yogyakartsa: Pustaka Pelajar. Plane,

Nugroho, S., \& Pitoyo, A. J. (2017). Arus Migrasi Risen di Indonesia Tahun 1980-2010. Jurnal Bumi Indonesia, 6, $1-9$.

http://lib.geo.ugm.ac.id/ojs/index.php/j bi/article/viewFile/906/879

Rahmawaty, D. (2014). Analisis Faktor Yang Mempengaruhi Ketimpangan Spasial Kabupaten/Kota Di ProvinsiBanten Tahun 20012013.Http://Eprints.Undip.Ac.Id/4523 O/, 103.

Sukowati, J. L. (2019). $\quad \begin{array}{llll}1 & 2 & 1,2 .\end{array}$ 3(November), 75-87.

Syamsir, A., \& Rahman, A. (2018). Menelusur Ketimpangan Distribusi Pendapatan Kabupaten dan Kota. EcceS (Economics, Social, and Development Studies), 5(1), 22. https://doi.org/10.24252/ecc.v5i1.5235

Sadono Sukirno. 2009. Mikro Ekonomi: Teori Pengantar. Jakarta: Raja Grafindo Persada

Sjafrizal. 2008. Ekonomi Regional Teori Dan Aplikasi. Baduose Media. Padang Sumatera Barat

Todaro, Michael P \& Stephen C. Smith. (2003). Economic Development. Eight Edition. England: Pearson Education Limited

United Nations. (1973). Determinants and Consequences of Population Trends. New York: Department of Economics and Social Affairs. 